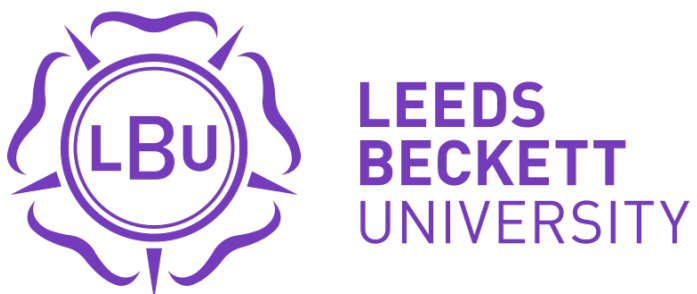

Citation:

Font, X and Garay, L and Jones, S (2016) A Social Cognitive Theory of sustainability empathy. Annals of Tourism Research, 58. pp. 65-80. ISSN 0160-7383 DOI: https://doi.org/10.1016/j.annals.2016.02.004

Link to Leeds Beckett Repository record:

https://eprints.leedsbeckett.ac.uk/id/eprint/2917/

Document Version:

Article (Accepted Version)

The aim of the Leeds Beckett Repository is to provide open access to our research, as required by funder policies and permitted by publishers and copyright law.

The Leeds Beckett repository holds a wide range of publications, each of which has been checked for copyright and the relevant embargo period has been applied by the Research Services team.

We operate on a standard take-down policy. If you are the author or publisher of an output and you would like it removed from the repository, please contact us and we will investigate on a case-by-case basis.

Each thesis in the repository has been cleared where necessary by the author for third party copyright. If you would like a thesis to be removed from the repository or believe there is an issue with copyright, please contact us on openaccess@leedsbeckett.ac.uk and we will investigate on a case-by-case basis. 


\title{
9948 words
}

\section{A SOCIAL COGNITIVE THEORY OF SUSTAINABILITY EMPATHY}

\begin{abstract}
Social-cognitive theory is used to test the argument that the motivations behind sustainable tourism, and the types of sustainable actions undertaken, depend on one's empathy towards sustainability. Latin American businesses were surveyed about their motivations for acting sustainably and any sustainability actions undertaken. Based on their responses, TwoStep cluster analysis found four clusters (cost, legitimisation, biospheric, and lifestyle). Acceptance of responsibility to be more sustainable depends on one's level of empathy with, and attachment to, sustainability, explained by a beneficiary focus (personal norms that drive one to act to help oneself or others) and a cultural focus (acting in response to individualistic or collectivistic social norms). Lifestyle businesses are argued to be culturally individualistic but self-transcendent in benefit focus.
\end{abstract}

Keywords: collectivism, ethics, individualism, morality, self-serving, self-transcendence

\section{INTRODUCTION}

A greater mindfulness of people and their environment enables hoteliers to increase their customers' sustainable behaviour (Barber \& Deale, 2014). Repeated and enhanced mindfulness of a place, and its people's long-term wellbeing, can create in a person a sense of care, connectedness, belonging, and a bond with that place, which results in empathy. Thus, sustainability empathy is defined as one's ability to establish an emotional connection with the surrounding people and environment. In this study the concept of empathy is applied to explain how tourism staff, primarily owners/managers of small and medium sized enterprises (SMEs), make sense of what sustainability means to them as a result of their background and motivations.

This paper uses Bandura's Social Cognitive Theory (SCT) $(1986,1991,2000,2002)$ to explain how the motivations of, and types of action taken by, individuals depend on their empathy towards sustainability. SCT proposes that behaviour, environmental factors, and personal factors are reciprocal, albeit not all of the same strength or occurring at the same time. In a cyclical fashion, one's behaviour is determined by both the environment and one's personal characteristics; personal characteristics are further shaped by behaviour; and eventually one's behaviour and personality can influence one's environment. SCT has been used widely in health, communication, education and business, but has been rarely used to study sustainable tourism behaviour (Sampaio, Thomas, \& Font, 2012a, 2012b). Bandura's (1991) SCT of moral thought and action is of particular interest here because of his arguments regarding self-sanctions as regulatory mechanisms of moral agency.

SCT allows researching factors that encourage compliance with social and personal norms, and thus to contextualise other contemporary tourism research on the business case for sustainability. SCT argues that people choose from a wide range of sustainability actions based 
on their preferences and competencies, centred on the stakeholders and the environmental and cultural influences that shape them. SCT suggests that motivations and actions are situationally bound, and that individuals are more likely to see the moral consequences of actions with familiarity or proximity (Kreps \& Monin, 2011), which are pre-conditions for empathy. This article models the relation between sustainability beneficiary and cultural background to show how the congruence between personal norms and societal norms determines an individual's accepted responsibility towards being more sustainable.

Firstly, following the work of Stern and Dietz (1994), this paper argues that sustainability actions can be explained in relation to sustainability values and norms, and the beneficiaries of such actions. Egoism, collectivism, altruism, and principlism are the personal sustainability values and norms that, according to Batson (1994), explain which objects are valued. The self, other people, and the biosphere are three sets of valued objects, proven by Schultz (2001), that underpin environmental concern. For example, a tourism business can take energy-saving decisions primarily for financial reasons (while at the same time caring about climate change), place birdfeeders for the enjoyment of guests (and conservation), and provide flexible working hours to a widow for altruistic reasons (and to increase staff loyalty). Hence, this study considers the relation between actions taken and the primary reasons for acting.

Secondly, understanding the culture in which an individual operates helps to explain the expectations society places on that individual, and thus, how their personal norms are shaped by their culture's social norms. Hofstede (1980) classified social norms as ranging from individualistic to collectivistic, and subsequent research has divided the latter into in-group (our close family and peers) and institutional, out-group (the broader society) collectivism. The dominant Western social paradigm encourages individualism based on the concept of a level playing field within a market economy, while countries where the state does not satisfy society's basic needs have higher collectivism (Gelfand, Bhawuk, Nishii, \& Bechtold, 2004). But today's world is far more complex than these dualities, and owners/managers of tourism SMEs can resort to individualistic or collectivistic concepts according to the context; moreover, the two concepts can coexist and serve to reinforce a decision (Husted \& Allen, 2008). Hence, this study tests how culture influences sustainability motivations and behaviour in three Latin American countries, and is influenced by collectivism and individualism.

\section{THE BENEFICIARY FOCUS}

Sustainability empathy can be partly explained by the relationship between the person acting and the beneficiary of their sustainability actions. Likewise, the extent of a person's focus on the beneficiary is dependent on their personal values. Decisions made by tourism SMEs are often an extension of the owner/manager's personality and characteristics, and they tend to demonstrate local grounding (Shaw \& Williams, 2004), enacting values and habits beyond simply being shaped by profit (Fassin, Van Rossem, \& Buelens, 2011). The inclusion of society and the 
environment as integral parts of one's own identity supports the introduction of practices with a sustainability outcome even when not explicitly understood as such. The literature also shows how the reasoning behind the same actions may vary, with lower-level moral reasoning and behaviours being hedonistic or approval-oriented, while higher-level reasoning and behaviours are needs-oriented, often anonymous, incur a cost and result from moral principlism (Eisenberg, Fabes, \& Spinrad, 2007). The remainder of this section follows Schultz's (2001) outline of the relation between environmental values and valued objects, according to the self, others, and the biosphere.

Benefits for one's self are widely promoted in sustainable tourism literature, providing direct short-term savings and impacts on financial results for their business. A more holistic view of the benefits to ones' self, of accepting responsibility to become more sustainable, suggests that opportunities can arise from, for example, creating win-win relationships with stakeholders, reducing costs and/or risks, or deriving benefits from improved reputation and legitimacy (Carroll $\&$ Shabana, 2010). While some tourism studies suggest that improved environmental performance means improved economic performance (Inoue \& Lee, 2011; Kang, Lee, \& Hug, 2010), the literature is inconclusive (Griffin \& Mahon, 1997; Margolis \& Walsh, 2001; Pereira-Moliner, et al., 2015). The argument put forward here is that studies showing substantial win-win results use a narrow, self-serving definition of environmental management. For example, substantial savings measured by Hilton resulted from the introduction of energy/water/waste programmes (Bohdanowicz, Zientara, \& Novotna, 2011), while other aspects of pro-sustainability behaviour were not prioritised (Font, Walmsley, Cogotti, McCombes, \& Häusler, 2012). 'Doing well by doing good' suggests that doing good is subordinate (Kreps \& Monin, 2011) and results in shallow eco-friendly behaviour (Tilley, 2000).

The relation between environmental values and benefits to others is a less common driver for sustainability actions, and often there is some degree of compromise between self-serving and other-serving benefits. Sustainable tourism actions that benefit others could be typified (beyond the eco-savings trio of energy/water/waste management) as those that purposefully produce social and environmental benefits to an identifiable target; they are often the result of localised purchasing, staff benefits or community support (Font, et al., 2012). In tourism, sustainability actions responding to legitimisation are taken with less conviction than self-serving actions, and happen as an add-on to the business core purpose rather than shaping the business goals (Byrd, Bosley, \& Dronberger, 2009; Font, et al., 2012; Inoue \& Lee, 2011; McGehee, Lee, O'Bannon, \& Perdue, 2010). This is because altruistic sustainability is not part of normative behaviour in SMEs, who often report that sustainability is expensive and complex (Revell \& Blackburn, 2007).

Tourism literature has identified some lifestyle eco-entrepreneurs with Biospheric values; that is benefits for the wider world rather than identifiable individuals. These are pioneering, altruistic SME owners/managers who undertake sustainability actions to benefit the global environment 
and society (Ateljevic \& Doorne, 2000; Dewhurst \& Thomas, 2003; Tzschentke, Kirk, \& Lynch, 2004). Such individuals have the unusual combination of care for others and the planet through their world-views alongside higher agency beliefs (Sampaio, et al., 2012b), resulting in them implementing more sustainability actions (which are time consuming, costly or longer-term), placing more emphasis on conservation and social dimensions, and rarely mentioning external drivers as their reason for acting (Raviv, Becken, \& Hughey, 2013). Sustainability in SMEs owned/managed by these eco-entrepreneurs is embedded their habits and routines, since it is part of their DNA (Dahlstrand \& Biel, 1997). It follows that these owner/managers are more likely to explain their reasons for sustainability engagement using high-level moral reasoning, together with pride and a sense of 'doing the right thing' based on their personal norms (Eisenberg, et al., 2007; Schwartz, 1977; Stern \& Dietz, 1994).

\section{THE CULTURAL FOCUS}

Sustainability empathy can be explained further by considering the extent to which an individual feels detached or attached to a particular set of culturally bound social norms. Hofstede's (1980) work on cultural orientation explains the concepts of individualism versus collectivism; the concept is used here to explain how some individuals feel more closely connected to their society and environment than others. The social paradigm dominant in Western cultures is one that sees market economics as the root to progress. This is based on "liberal democracy with its focus on private property, atomised individualism, and procedural neutrality with limited government and liberal economics that focuses on self-interested individuals satisfying preferences in relatively free markets" (Kilbourne, Beckmann, \& Thelen, 2002:198). This social paradigm benefits those in power, and power creates social independence and individualism.

The argument is that "increased resources and independence from others cause people to prioritise self-interest over others' welfare" (Piff, Stancato, Côté, Mendoza-Denton, \& Keltner, 2012:4086). Powerful people tend to be strongly goal-oriented, which can make them lose sight of other people's viewpoints and ignore information that would make them question their beliefs (Magee \& Smith, 2013). Engagement with other stakeholders ranges from posturing to genuine engagement depending on the extent to which the individuals in charge of a business see themselves as part of a societal collective. Materialism, a typical expression of individualism (Spence, 1985), has a negative effect on environmental beliefs (Kilbourne \& Pickett, 2008), therefore self-centred individualists tend to engage with sustainability for their own benefit. Selfinterested individuals only act on environmental matters when they perceive the environmental threat is likely to affect them, because self-enhancement values have a narrow construal of the self and therefore correlate with self-interest (Schultz, et al., 2005).

The more individualist a country is, the more it relies on market-based mechanisms (Matten \& Moon, 2008), notwithstanding that "response to ethical situations is more complex than can be 
explained by a country designation" (Curtis, Conover, \& Chui, 2012:22). Yet there is evidence that businesses in emerging economies are more other-serving than in Western cultures due to their closer links to, and understanding of, short-term socio-economic needs and longer-term environmental degradation (Ashley, 2005; Carrieri, Da Silva, \& Pimentel, 2009; Moretti \& Campanario, 2009). The strength of institutions and governance in a country, and the trust its citizens has on those institutions serving their needs, determines the value and practice of collectivistic behaviour. Bandura's (2001) proxy agency suggests that when individuals cannot achieve their desired outcomes by themselves, they turn to others to do it on their behalf, with an expectation of reciprocity. Collectivist people have a contextual, externally-oriented cognitive and relational orientation in both their pro-social (Kraus, Piff, Mendoza-Denton, Rheinschmidt, \& Keltner, 2012) and pro-environmental behaviour (Schultz, et al., 2005). Social empathic efficacy promotes pro-social behaviour by being cooperative, helpful, and sharing (Bandura, Caprara, Barbaranelli, Pastorelli, \& Regalia, 2001).

The welfare of others has two dimensions: in-group collectivism refers to the care of those close to oneself (family, close friends), and institutional collectivism refers to the broader care of society. In-group collectivism is a duty-bound, relational approach to care, expected in many cultures, particularly when the state does not provide such care (Gelfand, et al., 2004). In-group collectivism is not only about caring for family members and friends; seeing customers as guests and suppliers as colleagues are a form of extended in-group collectivism. For example, Vives (2006) studied 1,300 businesses in Latin America and showed low levels of environmental and external activities (cultural activities, sports, health and well-being, education, assistance to lowincome groups, and community participation), but higher levels of internal activities (work-family issues, equity, health and well-being, and worker participation). Carvalho (2007) found that businesses that practice sustainability actions regard the social measures they implement (relating to employees, suppliers, and the local community) as more important than the environmental measures (resource efficiency, recycling, solid waste management, and environmental education).

SMEs use social grooming to restore control and rebalance inequity from being vulnerable due to their size (Kluegel \& Smith, 1986). This suggests a certain empathy for others because of their acknowledged dependence on them, but results from low-level moral reasoning based on self-preservation. Small businesses rely on their social capital, a concept that resides in the value of the individual's or the organisation's network and is defined as "the nature of power and meaning that exists as structures and mechanisms guiding everyday social practice" (Fuller \& Tian, 2006:287). This includes intangible assets that compose the guiding principles of long-term performance, such as: reputation, trust, legitimacy, and consensus (Russo \& Tencati, 2009), which are influenced by behaving responsibly towards partners, customers, and society in general. These small businesses do not want to quantify their social capital or look at sustainability in economic terms, even when such benefits are realised (Fassin, et al., 2011; Jenkins, 2006). 
Once in-group basic needs are met, caring extends to institutional out-group collectives in accordance with whom the entity empathises. For example, IPEA found that $57 \%$ of Brazilian businesses perform community activities for humanitarian reasons and $20 \%$ reported acting for religious motivations; their priority actions are social investments, primarily care and feeding targeted at children, health, leisure/recreation, and provision of professional development (IPEA, 2006). This results in part from the tradition of charity derived from Latin America's Catholic background (Schultz, 2001), followed by two business reasons: managing risks and looking for competitive advantages (Austin \& Team, 2004). Austin and Team also found that the single, most consistent reason given for accepting responsibility to be more sustainable were ethics and religious values, although economic reasons (increased profits, labour satisfaction) and stakeholder legitimisation (relationships, legislation) were still important. The literature to date has shown that the relation between sustainability beneficiaries and cultural background is complex, multi-layered and requires further study.

\section{STUDY METHODS}

The research for this paper was conducted in Brazil, Chile, and Argentina, purposefully outside the obvious East/West divide of previous individualism/collectivism cultural studies. In the GLOBE study of 64 societies, Latin America had the highest mean score for institutional collectivism values, but the lowest mean score for actual practices (i.e. group loyalty and societal welfare are highly valued but not practiced). In contrast, it had high in-group collectivism values and mean scores (family groups both value and actually look after each other, since they cannot rely on the state to do so) (Gelfand, et al., 2004).

An online questionnaire followed the content and structure of a previous European study (Font, Garay, \& Jones, forthcoming). The independent variables referred to personal (gender, age, and nationality) and business characteristics (business type, number of employees, years since business creation, if a family business, brand or chain affiliation, months with occupancy over $50 \%$, and customer origin) and business performance (current financial health and change in the last two years). Pro-sustainability behaviour nominal scale questions asked owners/managers to self-report on environmental, social, and economic measures undertaken, and the top four reasons to undertake pro-sustainability actions, and the barriers to implementing further measures.

Data collection varied. The Chilean National Tourism Board (Sernatur) administered the survey to a sample of 2,000 of a population of 16,000 businesses, achieving 465 responses in two weeks with two reminders. The Brazilian Ministry of Tourism facilitated a database of 33,376 businesses, resulting in 1,365 responses after two reminders. Finally, no national database of tourism businesses was available in Argentina, hence only one region was surveyed; the University (NAMES TO BE INSERTED AFTER REVIEWING) and the Ministry of Tourism of Misiones between them distributed the survey to a sample of 450 businesses and achieved 172 responses. In total 1,945 valid responses were received from the 2,002 returned. The volume of 
the three samples (in relation to population volume) was significant with a confidence level above $95 \%$, a margin of error below $5 \%$ and a suitable heterogeneity. The sample was $95.14 \%$ small enterprises (less than 50 employees), 4.5\% medium enterprises (50-249 employees), and only seven respondents $(0.36 \%)$ with 250 or more employees. Because there were no significant differences across the three nationalities, all results refer to the overall sample.

Frequencies and cross-tabulations of significant relationships were used to map the data. Results were not statistically different per country and non-response bias assessed by comparing early respondents with late respondents (Armstrong \& Overton, 1977). Cluster analysis was used to group respondents based on their motivations to introduce sustainability measures. Cluster analysis is useful for exploratory and theory testing models (Ketchen \& Shook, 1996; Punj \& Stewart, 1983) in part because the number of cluster groups is not set a priori, unlike for example in discriminant analysis. TwoStep cluster analysis uses the hierarchical clustering method in the second step to assess multiple cluster solutions, giving the possibility of automatically determining the optimal number of clusters for the input data. TwoStep analysis solves problems of the widely used clustering algorithms, k-means clustering and agglomerative hierarchical techniques (Bacher, 2000), becoming the optimal choice for analysing dichotomous variables (Bacher, Wenzig, \& Vogler, 2004).

\section{RESULTS}

TwoStep Cluster method was applied to the original data sample (without ordering the variables, as that produces slightly different results) to create clusters based on the input data (respondents' choices of pro-sustainability motivations as outlined in the literature). The two most reported reasons (environmental protection and improve society) gave no consistent results because their commonality made it difficult to infer cluster patterns. Including these two reasons in the TwoStep Cluster method distorted the quality of clusters, measured in terms of the cohesion and separation silhouette, resulting in a less than 0.5 coefficient. This silhouette measure averages, over all records, $(\mathrm{B}-\mathrm{A}) / \max (\mathrm{A}, \mathrm{B})$, where $\mathrm{A}$ is the record's distance to its cluster centre and $\mathrm{B}$ is the record's distance to the nearest cluster centre that it does not belong to. A silhouette coefficient of 1 would mean that all cases are located directly on their cluster centres. A value of 0 means, on average, cases are equidistant between their own cluster centres and the nearest other cluster.

However, the motivations "to reduce business risks due to environmental degradation", "it's my lifestyle", and "to reduce costs" delivered consistent results in the form of four clusters labelled Cost, Legitimisation, Biospheric, and Lifestyle presented in Table 1 in ascending order of the number of sustainability practices reported, which could be explained in relation to beneficiaries and culture. Cluster naming took place after understanding all the characteristics outlined in the results section, consistent with hierarchical clustering, while the labels were applied retrospectively to facilitate reading of the results section of the article. The statistical fit of this analysis was excellent ( 0.7 in the silhouette measure of cohesion and separation) 
(Kaufman \& Rousseeuw, 1990), the cluster sizes were optimal (23.5\%, 23.7\%, 24.6\% and 28.2\%), and all the predictors had enough relative importance in conforming to the clusters (1.1 and 0.7$)$.

Table 1. Sustainability motivation clusters and main predicting reasons

\begin{tabular}{|c|c|c|c|c|c|c|c|c|c|c|c|c|c|}
\hline & \multirow[t]{2}{*}{$\mathbf{N}$} & \multicolumn{4}{|c|}{$\begin{array}{c}\text { To reduce business risks } \\
\text { due to environmental } \\
\text { degradation }\end{array}$} & \multicolumn{4}{|c|}{$\begin{array}{l}\text { It's a personal, } \\
\text { lifestyle choice }\end{array}$} & \multicolumn{4}{|c|}{ To reduce costs } \\
\hline & & & es & & & & es & & & & es & & No \\
\hline Costs & 479 & 0 & $0 \%$ & 479 & $36 \%$ & 0 & $0 \%$ & 479 & $34 \%$ & 479 & $58 \%$ & 0 & $0 \%$ \\
\hline Legitimisation & 457 & 0 & $0 \%$ & 457 & $34 \%$ & 0 & $0 \%$ & 457 & $33 \%$ & 0 & $0 \%$ & 457 & $41 \%$ \\
\hline Biospheric & 460 & 460 & $75 \%$ & 0 & $0 \%$ & 0 & $0 \%$ & 460 & $33 \%$ & 165 & $20 \%$ & 295 & $26 \%$ \\
\hline Lifestyle & 549 & 156 & $25 \%$ & 393 & $30 \%$ & 549 & $100 \%$ & 0 & $0 \%$ & 182 & $22 \%$ & 367 & $33 \%$ \\
\hline Total & 1945 & 616 & $100 \%$ & 1329 & $100 \%$ & 549 & $100 \%$ & 1396 & 100 & 826 & $100 \%$ & 1119 & $100 \%$ \\
\hline
\end{tabular}

Next, the clusters were compared against independent variables to better define business profiles that could be explained by the concepts of value to beneficiaries and/or culture, by analysing qualitative and categorical variables using cross-tabulations and chi-square statistics. The cluster columns in Tables 2, 3 and 4 show the percentage of respondents in a profile selecting that response. Bold cells show significant differences between clusters. In all cases zero cells $(.0 \%)$ have an expected count of less than $5 . \chi 2$ refers to the Chi-square value and $p$ to significance.

Respondents were asked to select four reasons for acting sustainably (see Table 2). To clarify, while Table 1 presented the distribution of answers for each motivation in relation to forming the clusters $(75 \%$ of all respondents motivated by "reducing business risk" fell within the biospheric cluster), Table 2 below shows the responses within each motivation for each cluster (i.e. all biospheric individuals were driven by a motivation to "reduce business risk"). The two top reported reasons are purely altruistic: protect the environment (67.4\%) and improve society $(51.0 \%)$. All others are business case or internal management driven. The reported barriers for not introducing more practices relate to money $(86.1 \%)$, cost $(61.9 \%)$, time $(41.8 \%)$, knowledge (40.7\%), motivation (29.6\%), demand (21.3\%), and perceived value (12.4\%).

Table 2. Motivations and Barriers for acting sustainably. Overall and cluster results

\begin{tabular}{|c|c|c|c|c|c|c|c|c|}
\hline & 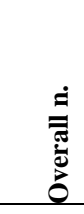 & 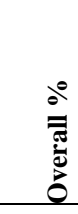 & $\sqrt{x}$ & 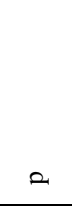 & $\begin{array}{l}0 \\
\text { o } \\
\dot{0} \\
\dot{0}\end{array}$ & 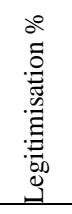 & 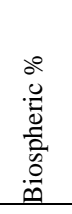 & 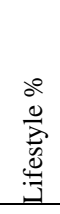 \\
\hline \multicolumn{9}{|l|}{ Motivations } \\
\hline To protect the environment & 1310 & 67.4 & 77.40 & 0.00 & 53.4 & 63.5 & 75.7 & $\mathbf{7 5 . 8}$ \\
\hline To improve our society & 992 & 51.0 & 59.71 & 0.00 & 39.9 & 47.5 & 51.3 & 63.4 \\
\hline For cost savings & 826 & 42.5 & 1013.95 & 0.00 & 100 & 0 & 35.9 & 33.2 \\
\hline Reduce business risks due to environmental degradation & 616 & 31.7 & 1428.96 & 0.00 & 0 & 0 & 100 & 28.4 \\
\hline It's a personal, lifestyle choice & 549 & 28.2 & 1945.00 & 0.00 & 0 & 0 & 0 & 100 \\
\hline
\end{tabular}




\begin{tabular}{|c|c|c|c|c|c|c|c|c|}
\hline To be more competitive in global markets & 541 & 27.8 & 95.33 & 0.00 & 32.4 & 41.8 & 24.1 & 15.3 \\
\hline For marketing and image benefits & 531 & 27.3 & 59.56 & 0.00 & 29.4 & 39.2 & 17.4 & 23.9 \\
\hline To improve business management data & 514 & 26.4 & 95.14 & 0.00 & 31.5 & 38.7 & 25.2 & 12.8 \\
\hline To meet legal requirements & 501 & 25.8 & 117.80 & 0.00 & 35.9 & 37.2 & 20.0 & 12.2 \\
\hline In response to customer demand & 349 & 17.9 & 93.02 & 0.00 & 17.3 & 32.4 & 13.2 & 10.4 \\
\hline To gain new information, advice and networks & 333 & 17.1 & 135.61 & 0.00 & 15.2 & 34.4 & 13.0 & 7.8 \\
\hline To improve business ' incomes & 190 & 9.8 & 46.80 & 0.00 & 12.5 & 16.2 & 6.5 & 4.7 \\
\hline To obtain subsidies or grants & 167 & 8.6 & 61.96 & 0.00 & 11.1 & 15.8 & 5.9 & 2.7 \\
\hline To meet the requirements of our chain/group & 158 & 8.1 & 43.89 & 0.00 & 8.1 & 14.9 & 6.7 & 3.6 \\
\hline To meet the requirements of a tour operator & 157 & 8.1 & 66.64 & 0.00 & 10.9 & 15.3 & 4.1 & 2.9 \\
\hline Because it was easy to implement & 26 & 1.3 & 12.13 & 0.00 & 0.4 & 0.9 & 1.1 & 2.7 \\
\hline \multicolumn{9}{|l|}{ Barriers } \\
\hline Lack of money & 1673 & 86.1 & 7.27 & 0.06 & 85.4 & 86.0 & 89.6 & 83.8 \\
\hline The perception of having higher costs & 1203 & 61.9 & 1.53 & 0.67 & 63.0 & 59.5 & 62.0 & 62.8 \\
\hline Lack of time & 812 & 41.8 & 14.51 & 0.00 & 37.4 & 38.3 & 42.4 & 47.9 \\
\hline Not knowing what to do & 792 & 40.7 & 1.08 & 0.78 & 39.3 & 41.8 & 39.8 & 41.9 \\
\hline Lacking motivation & 576 & 29.6 & 12.20 & 0.00 & 33.3 & 32.6 & 29.1 & 24.4 \\
\hline Customers not asking for it & 415 & 21.3 & 2.84 & 0.41 & 23.4 & 22.3 & 20.4 & 19.5 \\
\hline Believing that nobody will value it & 241 & 12.4 & 4.25 & 0.23 & 14.6 & 12.5 & 10.2 & 12.2 \\
\hline
\end{tabular}

The Cost Cluster included the specific motivation "For cost savings", and to a lesser extent "To be more competitive in global markets", "To improve business management data", and "To improve business' incomes". The Legitimisation Cluster is defined by not being influenced by the three main explanatory motivations but "To obtain subsidies or grants", "For marketing and image benefits", "To meet legal requirements", "In response to customer demand", "To gain new information, advice and networks", "To meet the requirements of our chain/group", and "To meet the requirements of a tour operator". The Biospheric Cluster included the motivations "To protect the environment", and to a lesser extent "To improve our society" and "To reduce business risks due to environmental degradation". The Lifestyle Cluster motivation is explained by the response "It's a personal, lifestyle choice", some business risk and cost motivations, and importantly an absence of stakeholder related motivations.

In the overall sample, respondents claimed to implement many sustainability practices (see Table 3), particularly environmental actions such as saving energy (79.7\%) and water (69.1\%), and encouraging customers to be environmentally friendly (59.6\%). The most reported social actions were generic, allowing aspirational answers (labelled as supporting, promoting...), whereas specific tangible or measurable actions that require more effort were reported less frequently. SMEs claimed to make local choices, both for selecting staff (74.0\%), suppliers $(38.7 \%)$, and products (66.9\%), and they encouraged customers to care about society $(35.7 \%)$ and the local area (32.3\%). It is also important to add that using cross-tabular analysis, no significant relationships were found between the number nor type of sustainability practices reported and the 
current or recent financial performance, as all the chi-squares tests had asymptotic significances below 0.05 .

Table 3. Sustainability practices- Overall and cluster results

\begin{tabular}{|c|c|c|c|c|c|c|c|c|}
\hline Environmental & 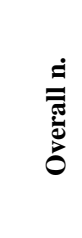 & $\frac{\sigma^{0}}{\bar{\pi}}$ & 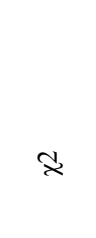 & 2 & $\begin{array}{c}0 \\
0 \\
\tilde{b} \\
\dot{\theta} \\
40.9\end{array}$ & 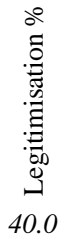 & $\begin{array}{c}0 \\
0 \\
\frac{0}{2} \\
\frac{1}{2} \\
\frac{0}{0} \\
44.8\end{array}$ & 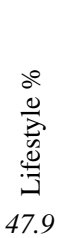 \\
\hline Save Energy & 1565 & 79.7 & 8.623 & $\mathbf{0 . 0 3}$ & 79.6 & 75.1 & 81.4 & 82.0 \\
\hline Save Water & 1357 & 69.1 & 7.529 & 0.05 & 72.6 & 64.5 & 69.0 & 69.9 \\
\hline Encourage customers be environmentally friendly & 1170 & 59.6 & 23.597 & 0.00 & 51.6 & 56.5 & 63.5 & 64.8 \\
\hline Use biodegradable products & 846 & 43.1 & 17.789 & $\mathbf{0 . 0 0}$ & 38.3 & 37.5 & 46.5 & 48.1 \\
\hline Choose environmentally friendly suppliers & 777 & 39.6 & 0.452 & 0.92 & 38.5 & 38.9 & 40.4 & 39.9 \\
\hline Recycle solid waste & 724 & 36.9 & 37.48 & $\mathbf{0 . 0 0}$ & 32.2 & 30.5 & 36.2 & 47.2 \\
\hline Conserve local biodiversity & 679 & 34.6 & 31.351 & 0.00 & 26.9 & 33.3 & 33.6 & 43.4 \\
\hline Recycle liquid waste & 327 & 16.7 & 4.805 & 0.18 & 17.9 & 13.5 & 16.8 & 18.2 \\
\hline Use renewable energy sources (solar, wind, biomass...) & 267 & 13.6 & 15.952 & $\mathbf{0 . 0 0}$ & 10.7 & 10.4 & 15.7 & $\mathbf{1 7 . 5}$ \\
\hline Social & & 38.5 & & & 35.4 & 37.5 & 39.0 & 41.6 \\
\hline Support local heritage conservation and culture & 1113 & 57.3 & 19.027 & $\mathbf{0 . 0 0}$ & 50.8 & 57.9 & 55.0 & 64.0 \\
\hline Promote gender equality in employment practices & 1024 & 52.7 & 16.102 & 0.00 & 48.7 & 47.2 & 55.7 & 58.0 \\
\hline Seek staff work- life balance & 921 & 47.4 & 10.432 & 0.01 & 43.6 & 45.2 & 47.4 & 53.0 \\
\hline Choose suppliers that demonstrate social responsibility & 751 & 38.7 & 2.868 & 0.41 & 38.3 & 38.3 & 36.4 & 41.5 \\
\hline Encourage customers to contribute to social initiatives & 693 & 35.7 & 17.341 & 0.00 & 31.8 & 39.6 & 30.3 & 40.4 \\
\hline Support local community development & 628 & 32.3 & 13.56 & 0.00 & 26.7 & 30.7 & 34.9 & 36.7 \\
\hline Adapt facilities for disabled people & 610 & 31.4 & 6.695 & 0.07 & 32.2 & 28.1 & 35.7 & 30.0 \\
\hline Offer job opportunities to disabled people & 236 & 12.1 & 13.49 & $\mathbf{0 . 0 0}$ & 10.8 & 12.7 & 16.4 & 9.1 \\
\hline Economic & & 58.7 & & & 56.8 & 56.7 & 60.2 & 61.4 \\
\hline Choose local staff wherever possible & 1438 & 74.0 & 3.165 & 0.36 & 75.6 & 72.8 & 76.0 & 71.9 \\
\hline Prioritise purchasing local products & 1301 & 66.9 & 16.09 & $\mathbf{0 . 0 0}$ & 64.5 & 62.3 & 66.2 & 73.4 \\
\hline Encourage customers to consume/use local products & 1195 & 61.5 & 10.857 & 0.01 & 57.6 & 59.8 & 60.3 & 67.0 \\
\hline Provide additional staff benefits (monetary and non-monetary) & 1012 & 52.1 & 5.019 & 0.17 & 49.6 & 52.1 & 55.0 & 54.2 \\
\hline Offer staff training programs & 763 & 39.2 & 6.169 & 0.10 & 36.8 & 36.6 & 43.4 & 40.3 \\
\hline
\end{tabular}

Table 4 shows the sample characteristics. The proportion of owners $(74.8 \%)$ does not vary from the European sample but the proportion of female respondents (39.3\%) is lower (Font, et al., forthcoming). These are largely independent family businesses (73.6\%), less than five years old $(43.0 \%)$, with average financial health $(60.6 \%)$, improving in the last two years $(51.9 \%)$, and with mostly domestic customers (86.9\%). These are primarily accommodation businesses (40.2\%), travel agencies $(34.8 \%)$ and transport companies (11.8\%).

Table 4. Sample characteristics. Overall and cluster results

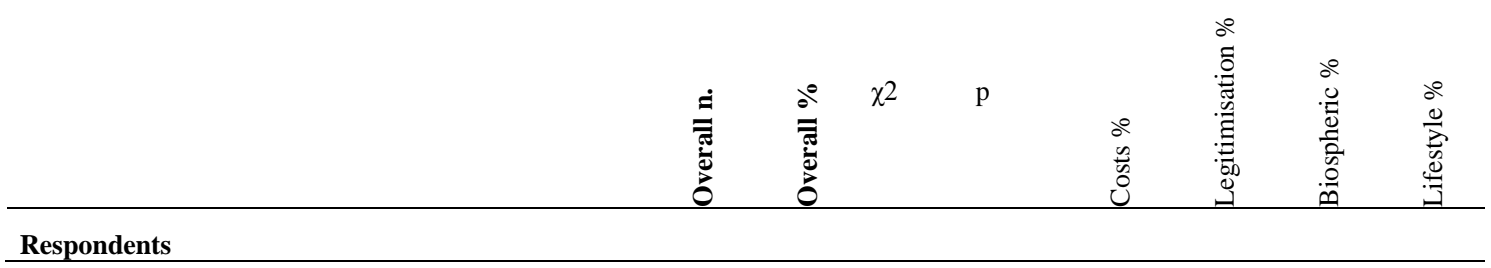




\begin{tabular}{|c|c|c|c|c|c|c|c|c|}
\hline Gender: Female owners/managers & 568 & 39.3 & 8.00 & 0.05 & 36.1 & 35.2 & 42.8 & 43.1 \\
\hline Businesses managed by their owners & 1089 & 74.8 & 27.11 & 0.00 & 69.2 & 78.4 & 68.9 & 81.6 \\
\hline \multicolumn{9}{|l|}{ Businesses } \\
\hline Family Businesses & 1075 & 73.6 & 1.17 & 0.76 & 74.2 & 71.6 & 75.2 & 73.3 \\
\hline Brand/chain affiliated & 102 & 7.1 & 8.83 & 0.03 & 9.2 & 8.2 & 7.2 & 4.1 \\
\hline Less than five years in operation & 625 & 43.0 & 4.32 & 0.88 & 44.9 & 43.3 & 40.7 & 42.5 \\
\hline Five or fewer full time employees & 823 & 57.3 & 45.42 & 0.00 & 55.6 & 61.3 & 47.7 & 62.9 \\
\hline Poor financial health & 242 & 16.6 & 3.53 & 0.74 & 15.7 & 15.2 & 18.4 & 17.3 \\
\hline Average financial health & 883 & 60.6 & 3.53 & 0.74 & 60.9 & 63.0 & 56.8 & 61.4 \\
\hline Good financial health & 331 & 22.7 & 3.53 & 0.74 & 23.4 & 21.8 & 24.8 & 21.3 \\
\hline Financial situation has improved in the last two years & 753 & 51.9 & 2.45 & 0.87 & 51.4 & 51.1 & 52.6 & 52.5 \\
\hline Financial situation stayed the same in the last two years & 484 & 33.4 & 2.45 & 0.87 & 35.4 & 33.9 & 32.8 & 31.3 \\
\hline Financial situation worsened in the last two years & 214 & 14.7 & 2.45 & 0.87 & 13.2 & 15.0 & 14.6 & 16.1 \\
\hline Domestic customers & 1634 & 86.9 & 5.29 & 0.15 & 90.0 & 86.5 & 85.9 & 85.4 \\
\hline International customers & 246 & 13.1 & 5.29 & 0.15 & 10.0 & 13.5 & 14.1 & 14.6 \\
\hline Accommodation business & 776 & 40.2 & 72.68 & 0.00 & 36.4 & 34.7 & 51.0 & 39.1 \\
\hline Restaurants & 153 & 7.9 & 72.68 & 0.00 & 10.5 & 6.8 & 8.3 & 6.2 \\
\hline Travel agency or tour operator & 671 & 34.8 & 72.68 & 0.00 & 33.7 & 37.3 & 27.6 & 39.6 \\
\hline Adventure tourism business & 17 & 0.9 & 72.68 & 0.00 & 0.6 & 0.9 & 0.7 & 1.3 \\
\hline Tourism guidance services & 16 & 0.8 & 72.68 & 0.00 & 0.0 & 1.3 & 1.1 & 0.9 \\
\hline Transport & 227 & 11.8 & 72.68 & 0.00 & 16.2 & 14.3 & 9.0 & 8.1 \\
\hline Events, Conventions, Conferences business & 64 & 3.3 & 72.68 & 0.00 & 2.5 & 4.0 & 4.4 & 2.5 \\
\hline Thematic Parks & 6 & 0.3 & 72.68 & 0.00 & 0.0 & 0.7 & 0.2 & 0.4 \\
\hline
\end{tabular}

\section{DISCUSSION}

This section justifies how the concept of sustainability empathy for society and/or the environment demonstrated by individuals explains an affection that depends on whether they undertake self-serving sustainability actions or other-serving actions, and whether they do so from an individualistic or collectivistic value system. This in turn affects and explain their behaviour. Schwartz's (1977) norm-activation model of altruism suggests that environmental concern arises from an awareness of impacts on a value or valued object. Using Schwartz's (1994) higher-order values, Schultz (2001) found that self-enhancement correlates with egoism, and selftranscendence correlates with altruism and biospheric behaviours (sharing similar value basis to each other). Most of the literature argues that individualists prioritise the rights of the self, while collectivists give preference to the in-group (the group they belong to) over the out-group (society in general, but also groups different to themselves) (Husted \& Allen, 2008). Figure 1 presents a sustainability empathy model with an increasingly inclusive view of who is in the in-group, hence this awareness of a wider inter-dependency.

\section{Figure 1 Sustainability empathy}




\begin{tabular}{|c|c|c|c|}
\hline & COLLECTIVISM & $\begin{array}{l}\text { Legitimisation } \\
\text { I am aware of my in- } \\
\text { group stakeholder } \\
\text { expectations and I } \\
\text { respond to appease them }\end{array}$ & $\begin{array}{c}\text { Biospheric } \\
\text { I am influenced by the } \\
\text { broader societal } \\
\text { collective needs and I act } \\
\text { for our collective benefit }\end{array}$ \\
\hline $\begin{array}{l}\text { Who influences } \\
\text { my behaviour? }\end{array}$ & INDIVIDUALISM & $\begin{array}{c}\text { Cost } \\
\text { I am aware of my own } \\
\text { needs and act to satisfy } \\
\text { them }\end{array}$ & $\begin{array}{c}\text { Lifestyle } \\
\text { I am shaped by society's } \\
\text { needs and I take } \\
\text { responsibility to act for } \\
\text { our collective benefit }\end{array}$ \\
\hline
\end{tabular}

SELF

OTHER

\section{BENEFICIARY: Whom do I want to help?}

Source: Own elaboration

Costs

The Costs Cluster in Table 3 has a higher (63.9\%) proportion of men in supervisory positions and of non-owners managers (30.8\%). These are expected to be managerial but to have lower budget discretion than the owners, therefore utilitarian and less concerned with the needs of others. They would be expected to be more defined by their socio-economic status (Kraus, et al., 2012), and as such to be more independent and self-contained. This is the group with the highest average $(9.2 \%$ against $7.1 \%$ overall) of brand/chain affiliated businesses and where restaurants (10.5\% against $7.9 \%$ overall) are an important typology. Males tend to develop ethical reasoning to comply with laws and to preserve social order, and prefer to take decisions based on objective and clear cut data (Jaffee \& Hyde, 2000; Stedham, Yamamura, \& Beekun, 2007). Moreover, El Dief \& Font (2012) also report that brand/chain affiliated businesses are usually engaged in cost-related sustainability. Accordingly, as Table 1 shows, $100 \%$ of the members of this cluster respond to cost saving reasons).

Based on Kreps and Monin (2011) it is argued that these individuals do not moralise, due to having a personal rather than group beneficiary focus, and therefore would not be expected to speak publicly about sustainability. This fits well with having mostly domestic customers $(90.0 \%$, see Table 3), who arguably have lower sustainability expectations (Skanavis \& Sakellari, 2011). "Lack of motivation" is a key barrier to act sustainably (33.3\% against $29.6 \%$ overall, see Table 1) confirming that they respond to instrumental benefits (Jaffee \& Hyde, 2000; Stedham, et al., 2007) despite environmental scepticism (Raviv, et al., 2013). Table 2 shows how members of this cluster show the lowest rates of implementation of social (35.4\% against $38.5 \%$ overall) and economic measures (56.8\% against 58.7\%). Water saving (73\% against $69 \%$ ) is practiced more 
frequently by this cluster, despite being below average on environmental measures generally (40.9\% against $43.7 \%)$.

Therefore the model in Figure 1 places the Cost Cluster in the bottom left corner because individuals within this cluster act based on an individualistic business case for personal benefit, where taking cost-saving actions offers the greatest paybacks. This cluster is well described in the current tourism literature arguing a business case for acting sustainably. Both the data from this research and previous literature suggest that broadening the scope of opinions considered by the business from self to others is the result of legitimisation, although the intentions are still a personal benefit.

\section{Legitimisation}

The Legitimisation Cluster is named based on the reasons and barriers reported (Table 1) and practices (Table 2), as the sample characteristics (Table 3) did not show any significance differences. Table 1 shows how respondents in this cluster are motivated by due-diligence issues, such as accessing new information (34.4\% against $17.1 \%$ overall) and subsidies (15.8\% against $8.6 \%$ overall), increasing business incomes ( $16.2 \%$ against $9.8 \%$ overall), management data (38.7\% against $26.4 \%$ overall) and competitiveness (41.8\% against $27.8 \%$ overall). Another group of reasons is directly related to stakeholder reporting, for example responding to customer demands (32.4\% against $17.9 \%$ overall) and meeting legal (37.2\% against $25.8 \%$ overall), touroperator (15.3\% against $8.1 \%$ overall) and business chain requirements (14.9\% against $8.1 \%$ overall). Another interesting result is that they do not report some reasons such as to reduce costs, to reduce business risks due to environmental degradation, or for lifestyle reasons $(0 \%$ in this cluster). Table 2 shows that businesses in this cluster introduce fewer than average sustainability actions (43\% against $45 \%$ overall) and specifically environmental (only $41 \%$ against $44 \%$ overall).

The wide range of motivations from these businesses suggests a heterogeneous group, sharing the outward-facing nature of their actions, and demonstrating some posturing (Font, et al., forthcoming). Their motivations and practices are explained by the fact that changing their beneficiary focus from individual to include others increases their workload, but also because moving on from operational cost-based actions requires more planning and is subject to human error. The argument is that although they are still utilitarian individualists, moral clarity decreases for this group as they deal with more complex sustainability and moral issues along with the needs and expectations of others. Those individuals that rely on moral clarity to take decisions, e.g. knowing for certain if a technological change deliver savings (Wiltermuth \& Flynn), may find it harder to engage with more nebulous sustainability issues that result from having to negotiate destination-wide actions for sustainability, which require time and lack certainty. When considering barriers, Table 1 shows how this group does not significantly report any barriers, but 
is one with the highest averages (63.0\% against $61.9 \%$ overall) in perceiving that sustainability implementation is related to higher costs. As Table 2 shows, these businesses do not stand out in any particular sustainability action (again one of the lowest in the economic actions, with only $56.7 \%$ and one of the lowest in the social practices, with 37.5\%). They do report high percentages for choosing environmentally responsible suppliers (38.9\% against $39.6 \%$ overall), socially responsible suppliers (38.3\% against $38.7 \%$ overall) and encouraging customers' to contribute to social initiatives (39.6\% against $35.7 \%$ overall).

Hence, the second cluster is placed at the top left-hand side, as the primary reason for acting becomes the acceptance of stakeholder expectations. Priming the in-group is a form of social grooming that introduces a bond and behaviours for others to reciprocate; therefore there is still an expected return on investment for the individual, but this is less certain as it depends on actions undertaken by the collective stakeholders and not the individual, so is less controllable. When actions with short, clear paybacks have already been implemented (for example, energy, water, waste management), any other options available are riskier or require higher investments, therefore the likelihood of benefits arising from their implementation is more nebulous (Kreps \& Monin, 2011). This is because the business has already accrued all the short payback efficiency gains from sustainability actions that appease its most demanding stakeholders.

\section{Biospheric}

Table 1 shows how this group significantly reports two environmental related reasons: to protect the environment (75.7\% against $67.4 \%$ overall) and especially to reduce business risks due to environmental degradation (100\% of their businesses, against $31.7 \%$ overall). These businesses have some economic motivations, and do not act because of lifestyle (which would suggest habitual sustainability). This group is motivated by environmental protection but does not reject other motivations, such as reducing costs (35.9\%) or being socially committed (51.3\%). This is the group least interested in image or marketing motivations (17.4\% versus $27.3 \%$ overall). These businesses claim that it is primarily money $(89.6 \%)$ and the perception of greater costs (62\%) that stops them from implementing more actions, but lack of time (42.4\%) is also relatively important, demonstrating lower self-efficacy belief and greater reliance on collective agency. Table 3 shows how this cluster is comprised mostly of accommodation businesses (51.0\% against $40.2 \%$ overall) and has the lowest proportion of businesses managed by their owners $(68.9 \%$ against $74.8 \%$ overall). It also has a low proportion of micro-enterprises with five or fewer full time employees ( $47.7 \%$ against $57.3 \%$ overall).

This cluster is therefore labelled "Biospheric" to maintain Schultz's (2001) terminology. It relates to reducing business risks due to environmental degradation, hence it still has a vested interest in sustainability. The environmental risks perceived by the Biospheric Cluster correspond to the consideration of future consequences reported by Milfont and Gouveia (2006) correlating with environmental preservation and institutional collectivism (Ashkanasy, Gupta, Mayfield, \& 
Trevor-Roberts, 1994). Their behaviour is more driven by personal norms (doing the right thing) than social norms (legitimisation) (Schwartz, 1977; Stern \& Dietz, 1994). Table 2 shows how businesses within the Biospheric Cluster undertake more pro-sustainability measures than those in either of the previous two clusters. In addition to measures that reduce direct environmental impacts, this group stands out in its implementation of measures outside the supply chain of the organisation i.e. those that can be explained by a broader social and environmental commitment, such as offering jobs to disabled people (16.4\% against $12.1 \%$ overall).

Hence, other people and the biosphere are valued depending on the degree to which they are part of an individual's cognitive representation of self (Schultz, 2000). The high, Latin American, in-group collectivism values and practices (Gelfand, et al., 2004) require individuals to respond to the needs of stakeholders that are close to them, and to be seen to be doing so. The model in Figure 1 suggests that having a more inclusive view of collectivism results in acting for biospheric benefits (Schultz, 2001; Stern \& Dietz, 1994). This occurs as in-group collectivism and stakeholder engagement goes beyond the economic-legal concept by accepting additional ethical responsibilities (Mitchell, Agle, \& Wood, 1997), which leads to institutional collectivism i.e. stakeholder engagement for the benefit of the society, not for self-serving purposes.

\section{Lifestyle}

Finally, the Lifestyle Cluster is the largest and most proactive one. Table 1 shows how these businesses act sustainably according to their values, habits and lifestyle, and are defined by making 'lifestyle' choices ( $100 \%$ of the group, against $28.2 \%$ overall). This group is notable in reporting environmental protection ( $75.8 \%$ against $67.4 \%$ overall) and improving society $(63.4 \%$ against $51.0 \%$ overall) reasons, but are not motivated by legitimising or public posturing. This group is the least motivated (by far, Sig. 0.00 ) in being more competitive (15.3\% against $27.8 \%$ overall), increasing income (4.7\% versus $9.8 \%$ overall), accessing new markets (15.3\% versus $27.8 \%$ overall), reducing costs (33.2\% against $42.5 \%$ overall), improving management data ( $12.8 \%$ versus $26.4 \%$ overall), obtaining subsidies ( $2.7 \%$ against $8.6 \%$ overall) or meeting chain requirements (3.6\% against $8.1 \%$ overall) or tour operator requirements $(2.9 \%$ versus $8.1 \%$ overall). Although their most reported barriers to introduce sustainability are lack of money and having higher costs, they significantly (Sig. 0.00) report a lack of time (47.9\% against $41.8 \%$ overall). Table 2 shows how individuals in this group implement a higher average of most environmental, social, and economic measures, that are more costly and longer-term than businesses those in other clusters.

Table 3 shows that members of this cluster are primarily micro-businesses with fewer than five employees, not brand affiliated, and with the highest proportions of businesses managed by their owners businesses (81.6\% against $74.8 \%$ overall) which provides more decision-making discretion (Thomas, Shaw, \& Page, 2011). This group has the highest proportion of female 
respondents (43.1\% versus 39.3 overall) and previous research has shown that females tend to display higher levels of sustainability actions as a result of a more nurturing and inclusive attitude towards society (Jones \& Gautschi, 1988). The reasons behind this increased other-serving approach are altruistic and lifestyle driven (Ateljevic \& Doorne, 2000; Carlsen, Morrison, \& Weber, 2008; Shaw \& Williams, 2004) which explains how they are often more satisfied with their income despite not earning more than the average (Garay \& Font, 2012). Despite remaining individualistic, they are self-transcendent by justifying pro-sustainability behaviour through higher-level moral reasoning (Eisenberg, et al., 2007) leading to choices that become internalised as habits. Sustainability lifestyle can lack agency (Bandura, 2001) by being habitual and less reflexive. But changing one's lifestyle to be more sustainable is a commitment; these individuals take personal responsibility for acting out the high Latin American institutional collectivism values (Gelfand, et al., 2004). These SMEs have the potential for high self-efficacy as they do not rely on large institutional structures to act (Sampaio, et al., 2012a; Shaw \& Williams, 2004). Therefore, it is possible to conclude that, within this cluster, there are bounded, contextualised selves, for whom altruism has become a self-realisation lifestyle.

In sum, the Lifestyle Cluster takes action for the collective good, but in a more individual way. Schultz construed the meaning of lifestyle as a self-enhancement value, yet the authors' interpretation is rather different. The authors propose that lifestyle is selfless because it is the result of choices made out of personal norms, not social norms. Batson's (1994) pro-social principlism explained how individuals adapt their behaviour according to selfless sacrifices beyond that expected by society, out of personal choice. Bandura's (2001) modes of human agency would suggest that individuals with high sustainability empathy and high personal agency beliefs, who live within a society with low institutional collectivism, would adopt individual approaches in spite of (or possibly because of) society's slower ability to self-regulate. How a cluster with individual culture but collective benefits exists can be explained is through Peng and Nisbett's (1999) concept of “deprivation-based preferences", whereby individuals show preference for things they find missing or take for granted. Basically, the less a society practices collectivism, the more it values it (Gelfand, et al., 2004). This explains the high desire in Latin America for out-group collectivism, and the fact that both this Latin American survey, and the previous European survey, found a large number of individuals willing to take action personally to restore such collectivism.

\section{CONCLUSIONS}

This study develops the conceptual model of sustainability empathy to explain sustainability behaviour in relation to a person's beneficiary focus (personal norms that drive one to act to help oneself or others) and a cultural focus (acting in response to individualistic or collectivistic social norms). In-group collectivistic societies emphasise localised socio-economic sustainability, in 
contrast to out-group concerns such as the global environment or, for example, disembodied social concerns in Europe. The literature shows that collectivistic societies focus on in-group members (people they can empathise with), while individualistic societies are more communal with outgroup members (Matsumoto, Kudoh, \& Takeuchi, 1996). Markus and Kitayama argue this is because people with interdependent self-construal get positive feelings by promoting others' goals, and from an emotion of psychological indebtedness, they "act in accordance with the perceived needs and desires of their partners in social relations" (1991:238). The ability to empathise is conditioned by an individual's self-efficacy beliefs, that is, the individual's trust in whether their actions results in their intended outcomes (Bandura, 1997). Based on the data, it is argued that the Cost Cluster and Lifestyle Cluster share high self-efficacy beliefs but for different reasons; the Cost Cluster relies on evidence-based management that produces short-term tangible results, while the Lifestyle Cluster focuses on the power of shared beliefs to take collective action (Bandura, 1997, 2002).

This study departs from previous literature in suggesting that the Lifestyle Cluster is culturally individualistic but self-transcendent in benefit focus. Collectivist cultures see social responsibilities in moral terms, while individualistic cultures see them as matters of personal choice (Miller, Bersoff, \& Harwood, 1990). This is because individuals marginalised by society perceive themselves to have less personal control over their situation and therefore rely more on social engagement, whereas social groups in power attribute an individual's social condition to their personal traits and effort not the context (Kluegel \& Smith, 1986). This, in turn, affects the perception of self-efficacy. An external locus of control is negatively related to environmental attitudes and behaviours (Geller, 1995), and the stronger the perceived collective efficacy, the higher the institutional collectivism (Bandura, 2000). The Lifestyle Cluster however shows that in contexts with low perceived collective efficacy (like Latin America, where institutional collectivism is low), individuals with a high self-efficacy can still act on behalf of the common good. Self-efficacy does not lead to selfishness and self-centred individualism (Bandura, 2001), but acting individualistically, rather than mobilising a collective, typically are associated with a lower expectation of return on investment by the individual who is making a personal sacrifice for the common good.

This paper finishes with some reflections on the limitations of the study. The definition of the clusters was limited to the businesses' motivations for acting sustainably. This clearly limits their explanatory value and the ability to test in full the concept of sustainability empathy. Expanding the research to consider psychosocial orientations, social customs, and governing mechanisms would provide a richer understanding of the role played by culture in sustainability decisionmaking. The authors asked for one set of motivations for a whole series of sustainability actions; clearly, this ought to be broken down and problematised. Additional research on the relation 
between cultural dependence, agency, and power, on sustainability awareness and practices could provide fruitful. Testing for dominant culture in the country of operation in comparison with the culture in the respondent's nationality and differences between intra-business cultural differences might provide further ground for research.

\section{REFERENCES}

1. Ashkanasy, N., Gupta, V., Mayfield, M., \& Trevor-Roberts, E. (1994). Future orientation. In R. House, P. Hanges, M. Javidan, P. Dorfman \& V. Gupta (Eds.), Culture, leadership and organisations: the GLOBE study of 62 societies (pp. 282-342). London: SAGE.

2. Ashley, A. P. (2005). Ética e Responsabilidade Social nos Negócios. São Paulo: Saraiva.

3. Ateljevic, J., \& Doorne, S. (2000). Staying within the fence: lifestyle entrepreneurship in tourism. Journal of Sustainable Tourism, 8, 378-392.

4. Austin, J. E., \& Team, S. (2004). Social Partnering in Latin America: Harvard University David Rockefeller Center for Latin American Studies.

5. Bacher, J. (2000). A probabilistic clustering model for variables of mixed type. Quality and Quantity, 34, 223-235.

6. Bacher, J., Wenzig, K., \& Vogler, M. (2004). SPSS twostep cluster: A first evaluation: Lehrstuhl für Soziologie.

7. Bandura, A. (1986). Social foundations of thought and action : a social cognitive theory. Englewood Cliffs, N.J.: Prentice-Hall.

8. Bandura, A. (1991). Social cognitive theory of moral thought and action. In W. M. Kurtines \& J. L. Gewirtz (Eds.), Handbook of moral behavior and development (Vol. 1, pp. 45-103). Hillsdale, NJ: Erlbaum.

9. Bandura, A. (1997). Self-efficacy: The exercise of control. New York: Freeman.

10. Bandura, A. (2000). Exercise of human agency through collective efficacy. Current Directions in Psychological Science, 9, 75-78.

11. Bandura, A. (2001). Social cognitive theory: An agentic perspective. Annual review of psychology, 52, 1-26.

12. Bandura, A. (2002). Social cognitive theory in cultural context. Applied Psychology, 51, 269-290.

13. Bandura, A., Caprara, G. V., Barbaranelli, C., Pastorelli, C., \& Regalia, C. (2001). Sociocognitive self-regulatory mechanisms governing transgressive behavior. Journal of personality and social psychology, 80, 125.

14. Barber, N. A., \& Deale, C. (2014). Tapping mindfulness to shape hotel guests' sustainable behavior. Cornell Hospitality Quarterly, 55, 100-114.

15. Batson, C. D. (1994). Why act for the public good? Four answers. Personality and Social Psychology Bulletin, 20, 603-610.

16. Bohdanowicz, P., Zientara, P., \& Novotna, E. (2011). International hotel chains and environmental protection: an analysis of Hilton's we care! programme (Europe, 20062008). Journal of Sustainable Tourism, 19, 797-816.

17. Byrd, E. T., Bosley, H. E., \& Dronberger, M. G. (2009). Comparisons of stakeholder perceptions of tourism impacts in rural eastern North Carolina. Tourism Management, 30, 693-703.

18. Carlsen, J., Morrison, A., \& Weber, P. (2008). Lifestyle Oriented Small Tourism Firms. Tourism Recreation Research, 33, 255-263.

19. Carrieri, A. d. P., Da Silva, A. R. L., \& Pimentel, T. D. (2009). O Tema da Proteção Ambiental Incorporado nos Discursos da Responsabilidade Social Corporativa. RAC, 13, 1-16. 
20. Carroll, A. B., \& Shabana, K. M. (2010). The business case for corporate social responsibility: a review of concepts, research and practice. International Journal of Management Reviews, 12, 85-105.

21. Carvalho, A., \& Alberton, A. (2007). Um estudo em estabelecimentos de hospedagem na Estrada Real/MG: as variáveis social e ambiental. Revista Hospitalidade, 5, 31-57.

22. Curtis, M. B., Conover, T. L., \& Chui, L. C. (2012). A cross-cultural study of the influence of country of origin, justice, power distance, and gender on ethical decision making. Journal of International Accounting Research, 11, 5-34.

23. Dahlstrand, U., \& Biel, A. (1997). Pro-Environmental Habits: Propensity Levels in Behavioral Change1. Journal of Applied Social Psychology, 27, 588-601.

24. Dewhurst, H., \& Thomas, R. (2003). Encouraging sustainable business practices in a non-regulatory environment: a case study of small tourism firms in a UK National Park. Journal of Sustainable Tourism, 11, 383-403.

25. Eisenberg, N., Fabes, R. A., \& Spinrad, T. L. (2007). Prosocial development. In N. Eisenberg (Ed.), Handbook of child psychology (pp. 646-718). London: Wiley.

26. Fassin, Y., Van Rossem, A., \& Buelens, M. (2011). Small-Business Owner-Managers' Perceptions of Business Ethics and CSR-Related Concepts. Journal of Business Ethics, 98, 425-453.

27. Font, X., Garay, L., \& Jones, S. (forthcoming). Sustainability motivations and practices in small tourism enterprises. Journal of Cleaner Production, http://dx.doi.org/10.1016/j.jclepro.2014.01.071.

28. Font, X., Walmsley, A., Cogotti, S., McCombes, L., \& Häusler, N. (2012). Corporate social responsibility: The disclosure-performance gap. Tourism Management, 33, 1544-1553.

29. Fuller, T., \& Tian, Y. (2006). Social and Symbolic Capital and Responsible Entrepreneurship: An Empirical Investigation of SME Narratives. Journal of Business Ethics, 67, 287-304.

30. Garay, L., \& Font, X. (2012). Doing good to do well? Corporate Social Responsibility Reasons, Practices and Impacts in Small and Medium Accommodation Enterprises. International Journal of Hospitality Management, 31, 328-336.

31. Gelfand, M., Bhawuk, D., Nishii, L., \& Bechtold, D. (2004). Individualism and collectivisim. In R. House, P. Hanges, M. Javidan, P. Dorfman \& V. Gupta (Eds.), Culture, leadership and organisations: the GLOBE study of 62 societies (pp. 437-512). London: SAGE.

32. Geller, E. S. (1995). Actively Caring for the Environment An Integration of Behaviorism and Humanism. Environment and Behavior, 27, 184-195.

33. Griffin, J., \& Mahon, J. (1997). The corporate social performance and corporate financial performance debate. Business \& Society, 36, 5.

34. Hofstede, G. (1980). Culture's consequences: International differences in work-related values. London: Sage.

35. Husted, B. W., \& Allen, D. B. (2008). Toward a model of cross-cultural business ethics: The impact of individualism and collectivism on the ethical decision-making process. Journal of Business Ethics, 82, 293-305.

36. Inoue, Y., \& Lee, S. (2011). Effects of different dimensions of corporate social responsibility on corporate financial performance in tourism-related industries. Tourism Management, 32, 790-804.

37. IPEA. (2006). A Iniciativa Privada e o Espírito Público: a evolução da ação social das empresas privadas no Brasil. Brasília: IPEA.

38. Jaffee, S., \& Hyde, J. S. (2000). Gender differences in moral orientation: a metaanalysis. Psychological bulletin, 126, 703.

39. Jenkins, H. (2006). Small business champions for corporate social responsibility. Journal of Business Ethics, 67, 241-256. 
40. Jones, T. M., \& Gautschi, F. H. (1988). Will the ethics of business change? A survey of future executives. Journal of Business Ethics, 7, 231-248.

41. Kang, K. H., Lee, S., \& Hug, C. (2010). Impacts of positive and negative corporate social responsibility activities on company performance in the hospitality industry. International Journal of Hospitality Management, 29, 72-82.

42. Kaufman, L. R., \& Rousseeuw, P. (1990). Finding groups in data: An introduction to cluster analysis: Wiley Series in Probability and Mathematical Statistics. Applied Probability and Statistics, New York.

43. Ketchen, D. J., \& Shook, C. L. (1996). The application of cluster analysis in strategic management research: an analysis and critique. Strategic management journal, 17, 441-458.

44. Kilbourne, W., Beckmann, S. C., \& Thelen, E. (2002). The role of the dominant social paradigm in environmental attitudes: A multinational examination. Journal of Business Research, 55, 193-204.

45. Kilbourne, W., \& Pickett, G. (2008). How materialism affects environmental beliefs, concern, and environmentally responsible behavior. Journal of Business Research, 61, 885-893.

46. Kluegel, J. R., \& Smith, E. R. (1986). Beliefs about inequality: Americans' views of what is and what ought to be: Transaction Publishers.

47. Kraus, M. W., Piff, P. K., Mendoza-Denton, R., Rheinschmidt, M. L., \& Keltner, D. (2012). Social class, solipsism, and contextualism: How the rich are different from the poor. Psychological review, 119, 546-572.

48. Kreps, T. A., \& Monin, B. (2011). "Doing well by doing good"? Ambivalent moral framing in organizations. Research in Organizational Behavior, 31, 99-123.

49. Magee, J. C., \& Smith, P. K. (2013). The Social Distance Theory of Power. Personality and Social Psychology Review, 17, 158-186.

50. Margolis, J. D., \& Walsh, J. (2001). People and Profits? The search for a link between a company's social and financial performance. Mahwah, NJ: Lawrence Erlbaum Associates.

51. Markus, H. R., \& Kitayama, S. (1991). Culture and the self: Implications for cognition, emotion, and motivation. Psychological review, 98, 224.

52. Matsumoto, D., Kudoh, T., \& Takeuchi, S. (1996). Changing patterns of individualism and collectivism in the United States and Japan. Culture \& Psychology, 2, 77-107.

53. Matten, D., \& Moon, J. (2008). "Implicit" and "explicit" CSR: A conceptual framework for comparative understanding of corporate social responsibility. The Academy of Management Review, 33, 404-424.

54. McGehee, N. G., Lee, S., O'Bannon, T. L., \& Perdue, R. R. (2010). Tourism-related social capital and its relationship with other forms of capital: An exploratory study. Journal of Travel Research, 49, 486-500.

55. Milfont, T. L., \& Gouveia, V. V. (2006). Time perspective and values: An exploratory study of their relations to environmental attitudes. Journal of environmental psychology, 26, 72-82.

56. Miller, J. G., Bersoff, D. M., \& Harwood, R. L. (1990). Perceptions of social responsibilities in India and in the United States: moral imperatives or personal decisions? Journal of personality and social psychology, 58, 33.

57. Mitchell, R. K., Agle, B. R., \& Wood, D. J. (1997). Toward a theory of stakeholder identification and salience: Defining the principle of who and what really counts. Academy of Management Review, 22, 853-886.

58. Moretti, S. L. d. A., \& Campanario, M. d. A. (2009). A Produção Intelectual Brasileira em Responsabilidade Social Empresarial - RSE sob a Ótica da Bibliometria. RAC

59. $13,68-86$. 
60. Peng, K., \& Nisbett, R. E. (1999). Culture, dialectics, and reasoning about contradiction. American Psychologist, 54, 741-754.

61. Pereira-Moliner, J., Font, X., Molina-Azorín , J. F., Lopez-Gamero, M. D., Tarí, J. J., \& Pertusa-Ortega, E. (2015). The Holy Grail: Environmental management, competitive advantage and business performance in the Spanish hotel industry. International journal of contemporary hospitality management, 27, 714-738.

62. Piff, P. K., Stancato, D. M., Côté, S., Mendoza-Denton, R., \& Keltner, D. (2012). Higher social class predicts increased unethical behavior. Proceedings of the National Academy of Sciences, 109, 4086-4091.

63. Punj, G., \& Stewart, D. W. (1983). Cluster analysis in marketing research: review and suggestions for application. Journal of marketing research, 134-148.

64. Raviv, C., Becken, S., \& Hughey, K. F. (2013). Exploring Values, Drivers, and Barriers as Antecedents of Implementing Responsible Tourism. Journal of Hospitality \& Tourism Research.

65. Revell, A., \& Blackburn, R. (2007). The business case for sustainability? An examination of small firms in the UK's construction and restaurant sectors. Business strategy and the environment, 16, 404-420.

66. Russo, A., \& Tencati, A. (2009). Formal vs. informal CSR strategies: Evidence from Italian micro, small, medium-sized, and large firms. Journal of Business Ethics, 85, 339-353.

67. Sampaio, A., Thomas, R., \& Font, X. (2012a). Small Business Management and Environmental Engagement. Journal of Sustainable Tourism, 20, $179-193$.

68. Sampaio, A., Thomas, R., \& Font, X. (2012b). Why are Some Engaged and Not Others? Explaining Environmental Engagement among Small Firms in Tourism. International Journal of Tourism Research, 14, 235-249.

69. Schultz, P. W. (2000). New Environmental Theories: Empathizing With Nature: The Effects ofPerspective Taking on Concern for Environmental Issues. Journal of social issues, 56, 391-406.

70. Schultz, P. W. (2001). The structure of environmental concern: Concern for self, other people, and the biosphere. Journal of environmental psychology, 21, 327-339.

71. Schultz, P. W., Gouveia, V. V., Cameron, L. D., Tankha, G., Schmuck, P., \& Franěk, M. (2005). Values and their relationship to environmental concern and conservation behavior. Journal of cross-cultural psychology, 36, 457-475.

72. Schwartz, S. H. (1977). Normative influences on altruism. Advances in experimental social psychology, 10, 221-279.

73. Schwartz, S. H. (1994). Are there universal aspects in the structure and contents of human values? Journal of social issues, 50, 19-45.

74. Shaw, G., \& Williams, A. M. (2004). From lifestyle consumption to lifestyle production: changing patterns of tourism entrepreneurship. In R. Thomas (Ed.), Small firms in tourism: International perspectives (pp. 99-114). Oxford: Pergamon.

75. Skanavis, C., \& Sakellari, M. (2011). International tourism, domestic tourism and environmental change: environmental education can find the balance. Tourismos, 6 , 233-249.

76. Spence, J. T. (1985). Achievement American style: The rewards and costs of individualism. American Psychologist, 40, 1285.

77. Stedham, Y., Yamamura, J. H., \& Beekun, R. I. (2007). Gender differences in business ethics: justice and relativist perspectives. Business Ethics: A European Review, 16, 163174.

78. Stern, P. C., \& Dietz, T. (1994). The value basis of environmental concern. Journal of social issues, 50, 65-84.

79. Thomas, R., Shaw, G., \& Page, S. (2011). Understanding small firms in tourism: A perspective on research trends and challenges Tourism Management, 32, 963-976. 
80. Tilley, F. (2000). Small firm environmental ethics: how deep do they go? Business Ethics: A European Review, 9, 31-41.

81. Tzschentke, N., Kirk, D., \& Lynch, P. A. (2004). Reasons for going green in serviced accommodation establishments. International journal of contemporary hospitality management, 16, 116-124.

82. Vives, A. (2006). Social and environmental responsibility in small and medium enterprises in Latin America. Journal of Corporate Citizenship, 2006, 39-50.

83. Wiltermuth, S., \& Flynn, F. Power, Moral Clarity, and Punishment in the Workplace. Academy of Management Journal, doi: 10.5465/amj.2010.0960. 